\title{
Occupational Safety and Occupational Health Law Protection in Garment Company $X$
}

\author{
Rosfiana $^{1}$, Evita Isretno Israhadi ${ }^{2}$ \\ Student Program Doctor of Law Borobudur University, J1. Pemuda, RT.1/RW.3, \\ Rawamangun, Kec. Pulo Gadung, DKI Jakarta 13220, Indonesia ${ }^{1}$, University of Borobudur, Jl. \\ Pemuda, RT.1/RW.3, Rawamangun, Kec. Pulo Gadung, DKI Jakarta 13220, Indonesia² \\ \{rosfiana@gmail.com ${ }^{1}$, riswadi@borobudur.ac.id ${ }^{2}$ \}
}

\begin{abstract}
Development requires several supporting factors such as capital, nature, and labor factors. These factors are signs that can't separate. The most crucial factor is the workforce that needs coaching and direction, and protection for the crew to create prosperity. This research method is a normative juridical to analyze and review problems related to law principles and principles. This study's result is the legal protection of labor in garment company $\mathrm{X}$ has been running well in the form of the provision of personal protective equipment and counseling, coaching and education to the workforce and the risks of its work. In conclusion, companies need to provide more safety and health equipment for workers.
\end{abstract}

Keywords: Occupational Safety; Occupational Health; Labor

\section{Introduction}

To build, we need supporting factors such as capital, nature, and labor factors. These three factors are critical, which is an inseparable linkage. But of these three labor factors become essential factors. Therefore, it requires coaching and direction, and labor protection to guarantee the workforce's welfare.

Legal protections and health protections for the workforce have become government work programs in almost all countries. In addition to human rights reasons, legal and health protection for the force is also a real effort to improve its productivity. Improving the quality of human resources has long been an influential agenda and even created a human development index to measure human resource performance effectiveness (Kahfi, 2016).

Today many companies use labor through Certain Time Labor Agreements to reduce labor costs to increase profits. However, in its implementation, many work agreements of a particular time are not under the provisions in Law No. 13 of 2003 on Employment that ultimately harms the workforce. This research aims to determine the legal protection of labor in implementing a specific time work agreement at a garment company.

The Ministry of Manpower has issued a new regulation on workplace health and safety that negates principles that took effect before 1964. The new rules provide new guidelines for chemical and physical threshold values and provide indoor air quality guidelines to create a viable workplace. Law No. 1 of 1970 on Occupational Safety and Health (occupational safety 
law) lays the basic principles of occupational safety implementation. Measures need to take to prevent accidents and explosions, reduce the likelihood of fire and fire management methods, and other standards set out concerning the workplace. The law also has rules on emergency exits, first aid in accidents, protection from pollution such as gases, sounds, and others; protection from occupational diseases; and safety equipment for workers.

\section{Methodology}

The nature of the research used by the authors in the writing of this study is descriptive research. Descriptive analysis is a study that intends to provide data as closely as possible. Descriptive research aims to systematically and accurately describe facts and characteristics regarding populations or concerning specific areas.

\section{Result and Discussion}

\subsection{Labour Health Protection}

Industrial Revolution 4.0 made the entire production process to the supply chain using machines. All of this is automatic, from raw materials and semi-finished goods to products. There applies from upstream to downstream, which causes many workers who companies do not absorb. However, the use of machines also requires the operation of skilled personnel. There gives rise to legal and health protections for workers who every day have to face the machine. In article 86 paragraph (1) of Law No. 13 of 2003, it stated that every worker has the right to obtain protection for:

a. occupational safety and health

b. morals and decency, and

c. treatment following human dignity and dignity and religious values

To protect workers and workers' safety from realizing optimal work productivity, organized occupational safety, and health efforts. Such protection implements according to the prevailing laws and regulations. To realize the protection of work safety, the government has made efforts to foster norms in Employment. In coaching, this norm already includes understanding the formation, application, and supervision of the model itself.

Work safety is closely related to work accidents that occur in the workplace or known as industrial accidents. This industrial accident, in general, can be interpreted as an unexpected and undesirable event that disrupts the regulated process of an activity. A particular occasion or event is the cause of this industrial accident/ work accident, in which there are 4 (four) contributing factors, namely:

a. For example, the Human Factor, due to lack of skill or lack of knowledge, is misplaced.

For example, the Secondary School of Technology (STM) workforce graduates but placed in the administrative department.

b. Material Factor/material/equipment, such as iron materials, is easier to make from other materials to cause accidents easily.

c. Danger factors, there are two reasons, namely: (1) Dangerous actions such as wrong work methods, fatigue/lethargy, not good work attitude, and (2) Hazardous conditions/circumstances that are unsafe from machines/equipment, environment, processes, and nature of work. 
d. Factors faced, such as the lack of maintenance/maintenance of machines/equipment, cannot work perfectly.

According to the International Labour Organization (ILO), several ways or steps need to be taken to cope with accidents that occur in the workplace, namely through: Legislation, Standardization, Inspection, Technical research, Medical research, Psychological research, Statistical research, Education, Exercise, Persuasion, and Insurance.

Health protection aims to enable the workforce to obtain a perfect mental, mental, and social state of health to enable optimal work. With the protection of occupational health to workers, the company will get benefits such as Improving and maintaining the highest level of labor health, both physical, mental, and social, Preventing and protecting the workforce from health problems caused by working environment conditions, Adjusting the crew to work or Employment with force and Improving work productivity.

A garment company PT X occupational health protection to do by providing worker benefits with BPJS Employment, a Workers and companies pay $5.7 \%$ of salaries. The calculation is that workers pay $2 \%$ and companies pay $3.7 \%$. These are the basis of the garment company's policy $-\mathrm{x}$ in providing health protection for its workforce.

\subsection{Labor Law Protection}

Every human being always needs a fee to make ends meet. To get the cost of living, one needs to work. Work can do independently or labor to others. Working for others can be done by working for a country. After this, referred to as an employee or working for another person (private) called a laborer or worker. But in reality, some workers have not earned their rights as they should. The protection of the law, is always related to power. Two powers are still a concern, namely the power of government and economic power. With government power, legal protection for the people, against the government (who rule). Regarding economic power, legal protection is protection for the weak (economy) against strength (economy), such as protection for workers against Employment (Supriyanto, 2020).

Legal protection is the protection of dignity and dignity and recognition of human rights possessed by traditional subjects based on the provisions of the law of arbitrariness or as a collection of rules or regulations that will protect something from other things. In Indonesia, the legal protection referred to always is based on Pancasila as the basis of the ideal. However, the concept of formulation uses western world thoughts whose concept emphasis rests on protecting human rights. Thus, merely the idea of the legal protection of workers in Indonesia remains based on protecting workers' dignity and dignity and their humanitarian rights, both individually and as workers.

Aspects of workers' protection include two fundamental things, namely protection from the power of employers and protection from government actions. Legal defense from employers' ability is to carry out if all parties implement the laws and regulations in the field of labor that require or force the employer to act as in the legislation because the law's enforceability can't be measured juridically only but measured sociologically and philosophically (Matompo, 2020). Protection of workers is expressly regulated based on Article 5 of Law No. 13 of 2003 on Employment. The article states that every worker has the same right and opportunity to obtain a decent job and livelihood regardless of gender, ethnicity, race, religion, and political flow following the workforce's interests and abilities, including equal treatment of persons with disabilities. Furthermore, Article 6 obliges employers to provide workers' rights and obligations without distinguishing gender, ethnicity, race, religion, color, and political flow. 
In detail, other rights this is also regulating under the Labor Law are containing in the following articles:

a. Article 11 contains the right to acquire and develop competencies

b. Article 12 paragraph (3) contains the right to attend (obtain) training

c. Article 31, jo; Article 88, states the right to choose the type of work and obtain Employment, both at home and abroad

d. Article 86 paragraph (1) states the right to occupational health and safety

e. Article 99 paragraph (1) contains the right of workers and their families to obtain social security workers (social security)

f. Article 104 paragraph (1), the right for workers to engage (form or become members) in the union/ labor.

Based on the content of the Labor Law articles, the scope of protection for workers includes:

a. Fundamental rights of workers to negotiate with employers;

b. Occupational safety and health;

c. Special protection for female, child, and disabled workers; and

d. Protection of wages, welfare, and social security of the workforce

According to Law No. 13 of 2003 at pt Garment Factory, legal protection for women's labor for reproductive health rights. X includes Maternity Cost Rights, Protection Rights During Pregnancy, Menstrual Leave Rights, Maternity Leave and Maternity Leave Rights, Miscarriage Leave Rights, Breastfeeding Leave Rights. Besides, the company also provides guarantees on financial protection by providing social security, social protection and occupational health, and occupational safety protection. So if we look at regulations related to Employment, garment company PT, this X has provided employment guarantees following the government's stipulated.

\section{Conclusion}

The conclusion that can convey from the results of this study is legal protection for women's labor on reproductive health rights according to Law No. 13 of 2003 at pt Garment Factory. X includes Maternity Cost Rights, Protection Rights during Pregnancy, Menstrual Leave Rights, Maternity Leave and Maternity Leave Rights, Miscarriage Leave Rights, Breastfeeding Leave Rights. The granting of applying the right, presumably less well carried out, because many factors affect it. In the implementation based on Law No.13 of 2003 on the cost of childbirth included in the social security program in Law No. 3 of 1992, that companies that have more than ten employees and pay wages as much as or more than $\mathrm{Rp}$ $1,000,000$ are required to enroll their employees in the social security program.

The implementation of the fulfillment of the right to protection of women's labor in pregnancy, which is a female worker who is pregnant, is in a very vulnerable condition because the excessive workload will affect the mother and baby's health in her womb. Therefore, the company guarantees protection for female workers who are pregnant. This protection ensures that pregnant female workers are free from performing tasks that harm their womb. There is lacking in its implementation because there is no difference in the work done between the female workforce who are pregnant and not. Of course, this is the absence of application of a company's guarantee free from duties that harm its content. 


\section{References}

[1] Ardita, Mikho. 2020. "Tanggung Jawab Negara Terhadap Jaminan Kesehatan Dalam Perspektif Hak Asasi Manusia.” Jurnal HAM 11(2): 319-33.

[2] Kahfi, Ashabul. 2016. "Perlindungan Hukum Terhadap Tenaga Kerja." Jurnal Jurisprudentie 3(2): 59-72.

[3] Matompo, Osgar Sahim. 2020. "Perlindungan Hukum Bagi Tenaga Kerja Asing Di Indonesia." Legal Standing: Jurnal Ilmu Hukum 4(2): 12.

[4] Sabrina, Qhisti. 2015. "Kebijakan Dan Manajemen Publik Pelaksanaan Program Jaminan Kesehatan Nasional (JKN) Dalam Peningkatan Kualitas Pelayanan Kesehatan Di RSU Haji Surabaya." Kebiijakan dan Manajemen Publik 3(2): 54-62.

[5] Sudrajat, Tedi, Siti Kunarti, and Abdul Aziz Nasihuddin. 2020. "Perlindungan Hukum Dan Pemenuhan Hak Pekerja Pada Program Jaminan Kesehatan Nasional.” Pandecta Research Law Journal 15(1): 83-92.

[6] Supriyanto, Eko Eddya. 2020. Eksistensi Nilai-Nilai Pancasila Dalam Kebijakan Ekonomi Indonesia. 1st ed. Malang: Literasi Nusantara.

[7] Yuniar, Yuyun, and Rini Sasanti Handayani. 2016. "Kepuasan Pasien Peserta Program Jaminan Kesehatan Nasional Terhadap Pelayanan Kefarmasian Di Apotek The Satisfaction of National Health Insurance P Rogram's Patients On Pharmaceutical Services in Pharmacy ( JKN ) Adalah Program Jaminan Berupa Bentuk Pel." Jurnal Kefarmasian Indonesia 6(1): 39-48.

[8] Wardhani, Lidya Christina. 2014. "Perlindungan Hukum Terhadap Tenaga Kerja Outsourcing Sebelum Dan Sesudah Putusan Mahkamah Konstitusi Nomor 100/PUUX/2002." 